\title{
Assessment of Bollgard II cotton pollen mediated transgenes flow to conventional cotton in the farming conditions of Burkina Faso
}

\author{
BOURGOU Larbouga ${ }^{1, \star}$, SANFO Denys ${ }^{1}$, TIEMTORE C. Bernard ${ }^{1}$, TRAORE Oula ${ }^{1}$, SANOU \\ Jacob $^{2}$ and TRAORE Karim ${ }^{1}$
}

${ }^{1}$ Institut de l'Environnement et de Recherches Agricoles (INERA). Programme Coton. 01 BP 208. BF-Bobo-Dioulasso 01, Burkina Faso.

${ }^{2}$ Institut de l'Environnement et de Recherches Agricoles (INERA). Programme Céréales Traditionnelles 01 BP 910 BFBobo-Dioulasso 01, Burkina Faso.

Accepted 31 July, 2013

\begin{abstract}
Cotton is the main cash crop in Burkina Faso. However, production is highly affected by bollworms and leafworms in the last years due to the spread out of the resistance of bollworms to most used pesticides. This has led to experiment on Bt cotton from 2003 to 2007 . The inevitable coexistence between transgenic and conventional cottons requires the assessment of transgene outflow. The study was carried out from 2004 to 2006, at Farako-Bâ, Boni and Kouaré. The presence/absence of transgenes was assessed using Bollgard II detection kits. The experimental design consisted of a Bt plot surrounded by a non-transgenic field. Different distances between the $\mathrm{Bt}$ and the non-transgenic field were considered. Application and non application of pest control measure was also taken into account. The results show that without insecticide application, the flow of transgene near the source at $2 \mathrm{~m}$ (4.63 $\%)$ was different and higher than those of more distant rates. With insecticide application, no transgene flow was detected at $\geq 25 \mathrm{~m}$ from the transgenic field. Study must be continued after commercial adoption to draw concrete conclusions and to suggest some strategies to prevent Bt cotton transgene outflow in Burkina Faso.
\end{abstract}

Key words: Transgenic cotton, Bollgard II cotton, Transgenes, transgene outflow, immunological test, Burkina Faso.

\section{INTRODUCTION}

Cotton is the main cash crop in Burkina Faso. In fact, it contributes to 50 to $60 \%$ of country total export incomes, 5 to $10 \%$ to the national GDP and involves more than three millions farmers (Lagandre, 2005). However, cotton production was highly affected during the past 20 years due mainly to the spread out of the resistance of bollworms to most used pesticides (Martin et al., 2000). The damaged caused by the pest particularly Lepidoptora as Helicoverpa armigera, account from 50 to $70 \%$ of the harvest without insecticides application (Traoré, 1999).
For many years, chemical means like pyrethroids spraying were used to control these pests attacks. However, since 1998, resistance was reported for many pests to the most common pesticide, the pyrethroids (Martin et al., 2000; Hema, 2004; Omer et al., 2009). The use of genetically-modified cotton plants (Bt cotton) represents one of the most promising alternative to the spraying of chemicals which are less and less effective (Vitale et al., 2008).

For a good management of the cotton pests, Burkina 
Faso has been the second country after South Africa to experiment the genetically modified cotton. This kind of cotton is capable to produce toxins in all parts of the cotton plant which defend the plant against Lepidoptera attacks (Perlak et al., 2001; James, 2002). The Bollgard II cotton or Bt cotton includes two genes from the common soil bacteria Bacillus thuringiensis $(\mathrm{Bt})$ which produce two toxins Cry1Ac et Cry2Ab controlling a broad spectrum of pests (Perlak et al., 2001).

But because transgenic cotton and conventional cotton will inevitably coexist, they probably could outcross. Several ways of gene flow were reported for transgenic crops like Bt cotton but the most studied remains the gene flow by pollen dispersal (Karieva et al., 1994; Llewellyn and Fitt, 1996; Wang et al., 1997; Vincenza and Marina, 2001; Berkey and Savoy, 2002; Van Deynze et al., 2005).

Pollen grain contains the genetic material which can be transferred to its progeny after flower fertilization. Several cultivated species are able to outcross with their relatives to exchange several characters (Mikkelsen et al., 1996; Chèvre et al., 1997; Squire et al., 1999; Messean et al., 2006). But generally, in cotton as in most other crops, several conditions must all exist or take place between the donor and recipient which suppose sympatric coexistence and co-flowering and production of fertile hybrids (Chèvre et al., 1997; Andow and Zwahlen, 2006). The assessment of transgene outflow and the associated consequences, case by case, is required before any approval (Chèvre et al., 1997; James, 2002). With the first herbicide-resistant genetically modified (GM) crops, the transgenes outflow was assessed by bioassying seeds presumed to be contaminated by using the corresponding herbicide (Berkey and Savoy, 2002; Messeguer et al., 2004; Van Deynze et al., 2005). With such bioassays, the transgene outflows were often overestimated because of the occurrence of false positives (Van Deynze et al., 2005).

Recently, with insect-resistant GM crops, transgene detection and identification is done by genetic amplification or by immune-enzymatic test ways (Berben et al., 2000). The proteins Cry $1 A c$ and Cry $2 A b$ produced by transgenes can be screened in leaves and seeds (Vincenza and Marina, 2001; Van Deynze et al., 2005). The efficiency of tests requires that screened proteins are expressed in sufficient quantity and are undamaged (Berben et al., 2000; Malone and Pham-Delegue, 2001).

A common study from the Canadian food inspection agency (Cfia) and the Plant biosafety office (Pbo) in 2003 indicated that Bollgard II cotton proteins expression level as well in grain $(43,2 \mu \mathrm{g} / \mathrm{g} / \mathrm{seed}$ fresh weight) as in the others parts of the plants are sufficient to be detected (Cfia and Pbo, 2003).

The objective of this study was to investigate through immunological tests the transgene outflow via the marked Bt pollen under Burkina Faso agro-ecological conditions. We have distinguished a case of zero insecticide treatment for a maximum outflow (2004 and 2005 at Farako-Bâ) and a situation of coexistence with treatments and varying distances (2006 at Boni and Kouaré) like as the standard practices in cotton production in Burkina Faso.

\section{MATERIALS AND METHODS}

\section{Site of the study}

The study was carried out in research centres in 2004 and 2005 at Farako-Bâ and in 2006 at Boni and Kouaré. Farako-Bâ (405 m altitude, $4^{\circ} 20^{\prime}$ West longitude and $11^{\circ} 06^{\prime}$ North latitude) and Boni (Altitude $349.3 \mathrm{~m}$ and $11^{\circ} 32^{\prime}$ North latitude and $3^{\circ} 26^{\prime}$ West longitude) belong to the most important cotton zone of Burkina Faso in the Western, between the isohyets 800 and $1000 \mathrm{~mm}$ while Kouaré belong to a small and new cotton zone in the Eastern with annual rainfall $\leq 900 \mathrm{~mm}$. In both Eastern and Western cotton zones, South-Soudanean climate is generally dominant. Vegetation is savanna to shrub with abundance of pollen producing plants like Acacia seyal (dell), Acacia nilotica ((L.) willd. ex dell) and nectar producing species like Parkia biglobosa (Jacq. R. Br. ex G. don.), Bombax costatum (Pellegr. et Vuillet), Vitellaria paradoxa (Gaertn. F.), Anacardium occidentale (L.) justifying abundance of pollinator' insects such as honey bees, bumble bees and butterflies.

\section{Genetic materials}

The genetic materials comprised five cotton varieties, that is, FK37, FK37 BG II (best adapted to the Western), STAM 59A, STAM 59A BG II (best adapted in the Eastern) and an American transgenic cotton variety DP50 BG II. FK37 BG II and STAM 59A BG II are also transgenics resulting from a cross between DP50 BG II and their conventional isogenics FK37 and STAM 59A to introgress Cry1 Ac and Cry2A genes. In 2004 and 2005, DP50 BG II and FK37 were used while in 2006, FK37 BG II and FK37 (at Boni) and STAM 59A BG II and STAM 59A (at Kouaré) were used.

Transgenic cottons were used as marked pollen donor while conventional ones were receptors. All varieties utilized in this study are Gossypium hirsutum species and they are more often coflowering in our cotton production system.

\section{Field experimental designs}

Both in 2004 and 2005 at Farako-Bâ, the experimental design was a $320 \mathrm{~m}^{2}$ marked pollen plot (DP50 BG II) surrounded by a $15 \mathrm{~m}$ wide contiguous field of conventional cotton (FK37). The central plot and the field were separated by a $2 \mathrm{~m}$ wide alley (Figure 1). Seeds were sown manually at a $80 \mathrm{~cm}$ inter row spacing and $40 \mathrm{~cm}$ intra row spacing. Latter thinning to two plants per sowing hole was done to ensure uniform stand. The standard agronomic practices were adopted through the crop-growing season with however no insecticides applied to ensure a maximum presence of pollinator insects (Vincenza and Marina, 2001; Hamilton et al., 2002).

In 2006 at Boni and Kouaré, the experimental design consisted of two central plots of transgenic and conventional cottons $(55 \times 20 \mathrm{~m}$ each) separated by a $2 \mathrm{~m}$ alley and surrounded by a $15 \mathrm{~m}$ band of non-transgenic cotton. The central plots and the $15 \mathrm{~m}$ band were separated by a $2 \mathrm{~m}$ alley (Figure 2 ).

In each site, it was possible to sample two distant conventional cotton fields separated from the transgenes source by wide open space. In Boni, these two fields were located at 63 and $300 \mathrm{~m}$ while at Kouaré they were at 106 and322 m. Standard agronomic practices were similar to those of Farako-Bâ. Differently, all conventional fields, except for the $15 \mathrm{~m}$ band, were treated six times and the transgenic field twice with pyrethroid and organophosphate mixture according to the local standard of cotton protection program in 


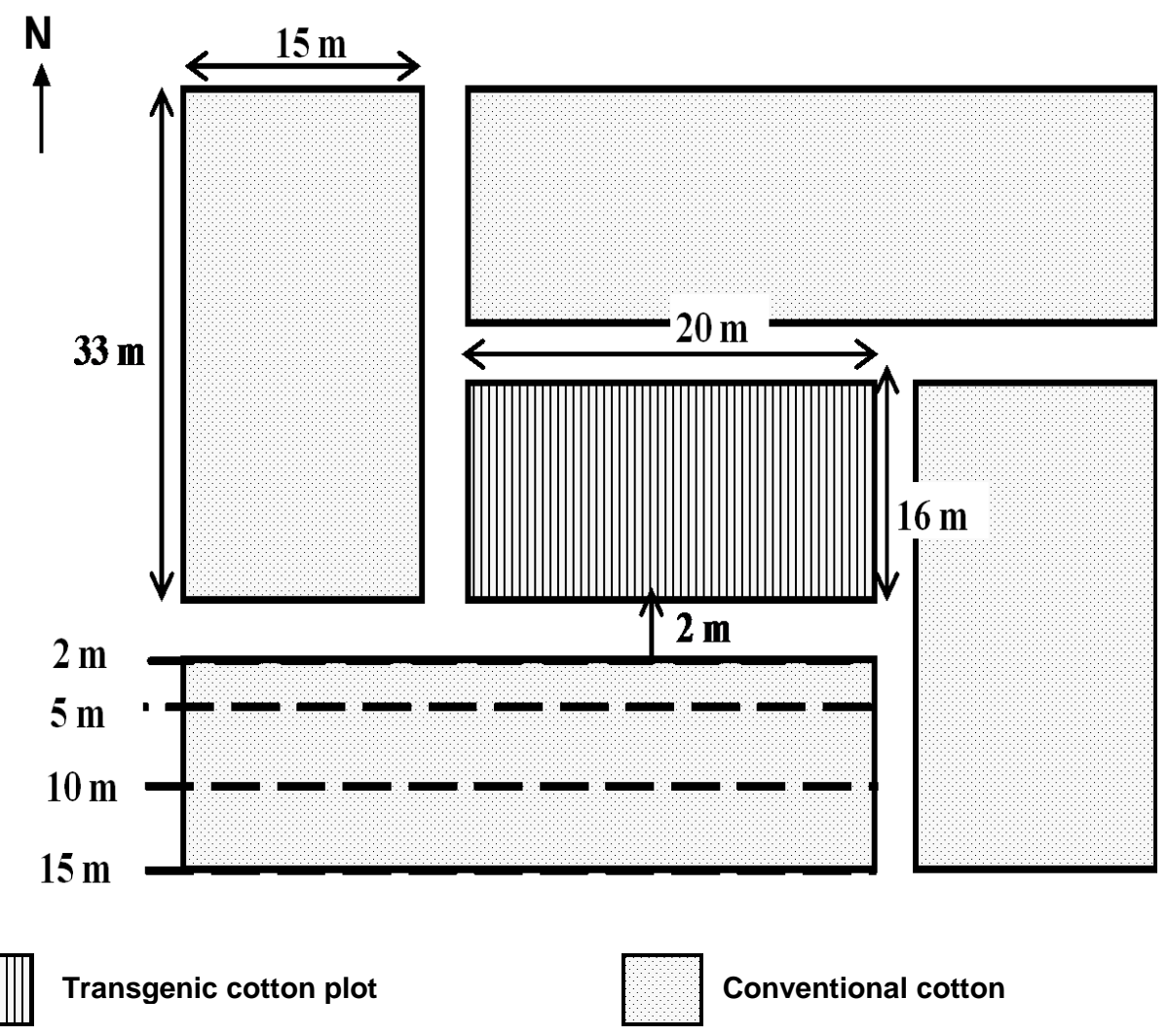

Figure 1. Illustration of the transgene outflow study experimental design in 2005 at Farako-Bâ.

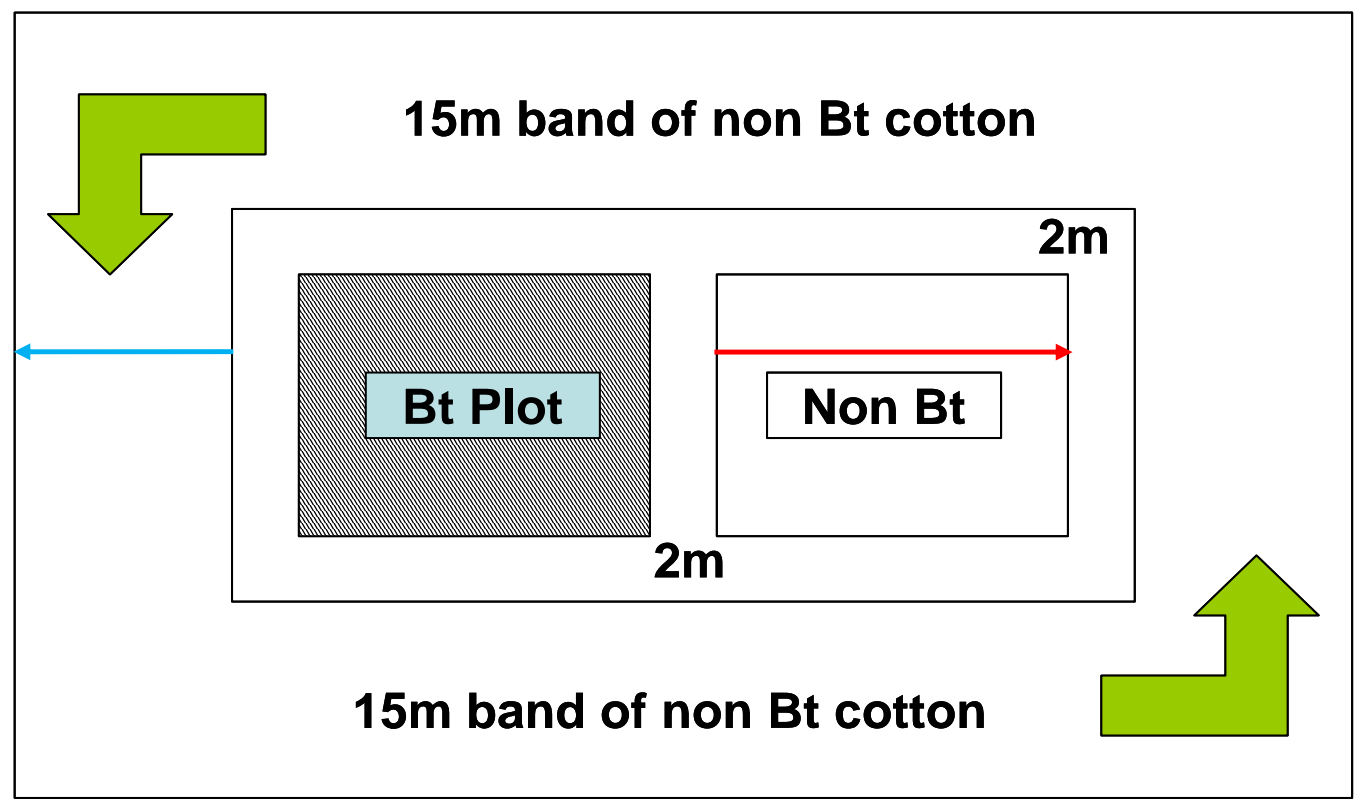

Untreated cotton sampling

Treated cotton sampling

Figure 2. illustration of the transgene outflow study experimental design in 2006 at Boni and Kouaré. 
Burkina Faso.

\section{Seed sampling}

On each site and each year, seed samples to be tested were harvested at maturity in the neighboring non-transgenic fields. Sampling was randomly done three times on each distance to be most valuable. Cottons bolls were picked out from lower, middle and upper branches to take into account possible season-effect as reported by Van Deynze et al. (2005). Then, the seed cotton was ginned and delinted and seed were randomly chosen to be tested.

At Farako-Bâ, sampling was carried out at 2, 5, 10 and $15 \mathrm{~m}$ from the marked pollen plot. In 2004, sampling was randomly made, for each distance, on a mixture of cotton from all the four sides. Then, 480 seeds (120 seeds $\times 4$ distances) were tested individually. In 2005 , to investigate the influence of geographical orientations on the flow, sampling was separately made per distance and per direction. Concerned that the North side has been treated once by mistake, we did not consider it. Then, 16,560 seeds (460 seeds $\times 3$ samples $\times 4$ distances $\times 3$ directions) were individually tested.

In 2006, both at Boni and Kouaré, the sampling distances were 2, $5,10,15,25,35,45$ and $55 \mathrm{~m}$ in the neighboring treated conventional field. Samples were also taken at 2, 5, 10 and $15 \mathrm{~m}$ in the untreated band (Figure 2). For each distance, 15 plants were harvested and 48 seeds per plant were randomly chosen; then a total of 720 seeds were tested individually. In the far fields, we considered 15 plants per distance and 100 seeds per plants tested simultaneously. The sampling distances were 64, 69, 74 and $80 \mathrm{~m}$ for the first field and 300,305 and $310 \mathrm{~m}$ for the second in Boni while they were 106, 111, 116, 121 and $322 \mathrm{~m}$ as well as 327,332 and $337 \mathrm{~m}$ for the two far fields in Kouaré.

\section{Biochemical assays}

The objective of the test was a verification of the presence or absence of toxins in the seeds, indicating the pollination or not by pollen from the transgenic plot. The immuno-enzymatic test detects proteins (Cry1Ac and Cry2Ab) produced by the transgenes. Then the presence of these interest proteins points out the presence of the Cry genes in the seed and vice versa. We used an immuneenzymatic detection kit provided in 2004 and 2005 by EnviroLogix Inc. (Portland, ME, USA). It consisted of an extraction buffer salts, a surfactant buffer and lateral flow strips. The technique of lateral flow test on strip is a system of detection with membranes including three capture zones fixed on a paper support in strip. Two captures zones are related to the bound transgenic protein and the last one captures color reagent.

At first, the extraction buffer was prepared by mixing $1 \mathrm{~L}$ distilled water, a content of one package of extraction buffer salts and $2.5 \mathrm{ml}$ of surfactant buffer. Seeds to be tested were cracked into small pieces using pestles. 1 to $2 \mathrm{~g}$ of the cracked cottonseed was put into a $1.5 \mathrm{ml}$ Eppendorf tube and was ground. To this, $1 \mathrm{ml}$ of the extraction buffer was added. Then, we let the tube with the cottonseed sample extract stand for 2 min while shaking intermittently to extract the proteins. 5 min after we stopped shaking, one lateral flow strip test was inserted into each Eppendorf tube containing seed sample extract and the sample migrated up the strip by capillarity action. We allowed the test strip to remain in the tube for about 10 min to develop and show lines before interpreting the test.

\section{Reading and interpreting the test}

For a good test, at least one line (the control line) should be shown. Results are positive for transgene presence when 2 or 3 lines are observed on the strip (including the control) at the end of capillary migration phase (picture 1): Upper line (control line) indicates that the strip functioned properly. This line appears even in absence of the searched proteins; median line indicates a positive result for Cry1Ac protein; lower line indicates a positive result for Cry2Ab protein.

Data recorded after analyses were percentage of transgene presence in progeny seeds as calculated according to the following formula (Van Deynze et al., 2005):

Transgene outflow $(\%)=\frac{\text { Number of seeds tested positive }}{\text { Total number of seeds tested }} \times 100$

\section{Statistical analysis}

All data from distances beyond $15 \mathrm{~m}$ from transgene source were zero and they were not considered in the analysis. Moreover, data from Farako-Bâ in 2004 were not used due to the weak number of tests performed. Data from individual tests less than $15 \mathrm{~m}$ from the source were pooled to generate means per distance and by side (2005). In 2006, each 48 individual tests were used to obtain means per plant and per distance. Then, parametric tests were carried out using the XLSTAT 6.1.9 Software to compare means generated two by two. The Fisher's $F$ test was used to compare the variances of data analyzed while the Student's $t$ test compared the means of rates.

To examine the relation between the transgene outflow and the distance from the source, we considered the untreated fields in three sides at Farako-Bâ (in 2005) and one side at each Boni (in 2006) and Kouaré (in 2006). Data of these objects for each distance were compared to other each distance. To investigate the relation between the outflow rates and the side regarding distance from the source, we compared data from Farako-Bâ in 2005 per distance and per side. To finish, we look into the influence of the pest control treatments on rates of transgene flow by comparing data from treated and untreated sides at each distance and considering all distances.

\section{RESULTS}

\section{Relation between the transgenes outflow and the distance from transgenes source}

Comparison two by two of outflow rates showed differences between the $2 \mathrm{~m}$ distance outflow rate and all the other for their variances and their means. According to the Fisher's $\mathrm{F}$ test, variance of rates at $2 \mathrm{~m}$ compared to those at 5, 10 and $15 \mathrm{~m}$ were significantly different (Table 1). Moreover, mean of outflow rate at $2 \mathrm{~m}$, that is, $4.63 \pm$ 2.34, was significantly different compared to those at $5 \mathrm{~m}$ $(1.45 \pm 1.49), 10 \mathrm{~m}(0.99 \pm 0.95)$ and $15 \mathrm{~m}(1.03 \pm 0.93)$. But there was no difference between rates at 5,10 and $15 \mathrm{~m}$ compared two by two.

\section{Relation between the outflow rates, direction and distance from transgenes source}

Outflow rates by side taking into account all the distances sampled indicated that there was no significant difference between means from East side, South side and West side compared two by two (Table 2). But on the bases of each distance taken separately, the Student's $t$ test 


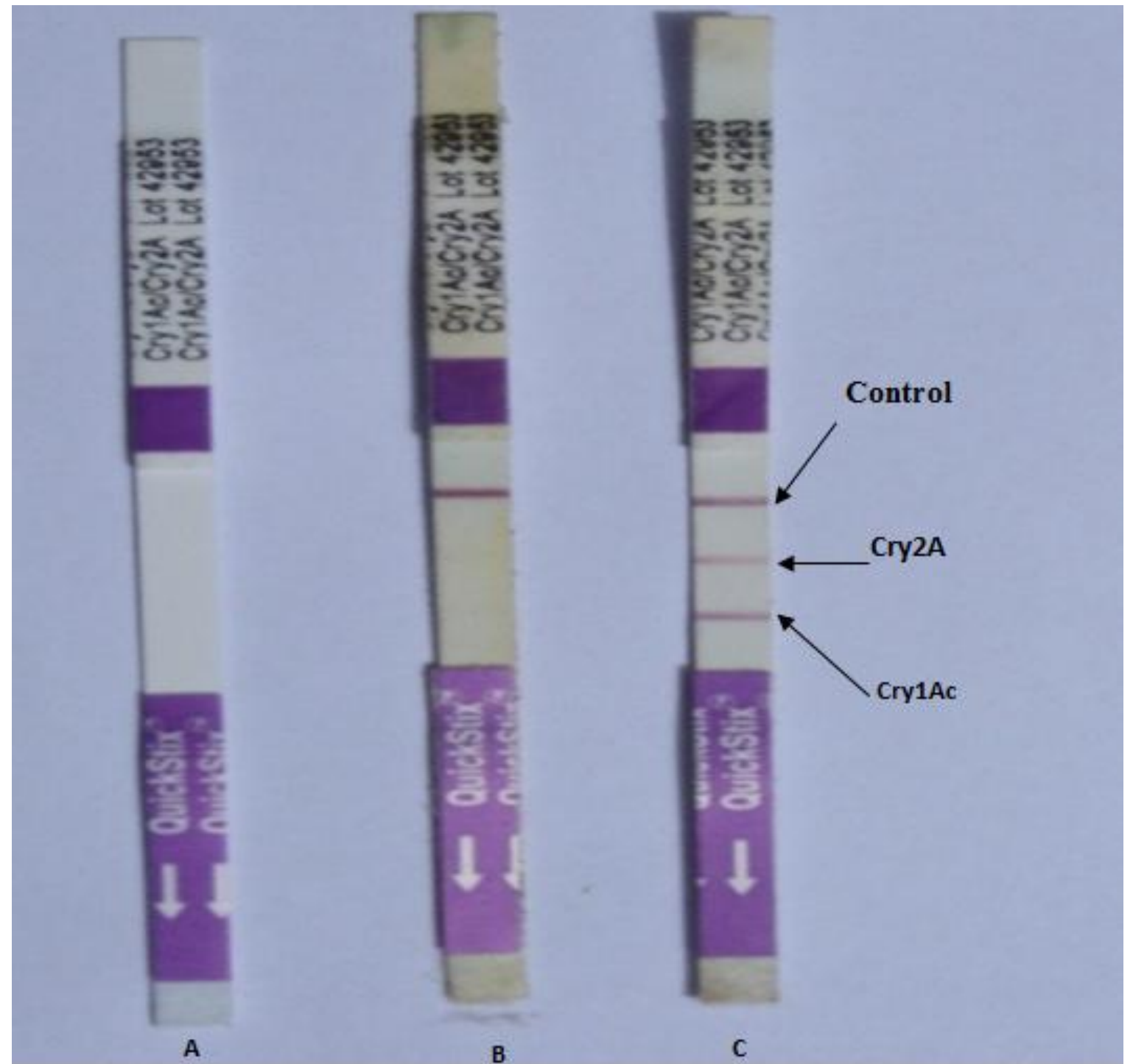

Picture 1. Illustration of test strip results. A, Unused strip; B, negative test; $C$, positive test for Cry1Ac and Cry2Ab.

revealed a significant difference between the East and the West means compared at $2 \mathrm{~m}$. There was also significant difference between the East and South means compared at $5 \mathrm{~m}$ but no significant difference was observed between the South and West regardless of the distance of comparison. As $15 \mathrm{~m}$ outflow rate in the West side was zero, it was not possible for the $F$ and $t$ tests with other sides (Table 2).

\section{Relation between the transgenes outflow and pest control treatments}

The Fisher's $\mathrm{F}$ test and Student's $\mathrm{t}$ test showed difference when conditions of pest control and without pest control treatment were compared. When the outflow rates compared took into account all the distances sampled, there were significant differences of variances (Boni and Kouaré) and means (Kouaré) between these two conditions (Table 3). When comparisons were made by distance, there was no difference in the immediate proximity of the source and significant difference appeared at $10 \mathrm{~m}$ (for $\mathrm{F}$ test) and at $15 \mathrm{~m}$ (for $\mathrm{F}$ and $\mathrm{t}$ test) in both Boni and Kouaré (Table 3). Beyond $15 \mathrm{~m}$ in both the contiguous field and far located fields, tests to detect transgene presence were negative.

\section{DISCUSSION}

This study was carried out prior to the adoption evaluation of Bt cotton in Burkina Faso from 2004 to 2006, on three sites. The concern about transgene flow was really justified given that genetically modified cotton varieties as well as currently cultivated varieties in Burkina Faso are G. hirsutum species. 
Table 1. Relation between transgene outflow and distance from transgene source.

\begin{tabular}{cc}
\hline $\begin{array}{c}\text { Objects compared } \\
\text { and tests used }\end{array}$ & $\begin{array}{c}\text { Means of outflow rates and } \\
\text { significance of tests }\end{array}$ \\
\hline $2 \mathrm{~m}$ & $4.63 \pm 2.34$ \\
$5 \mathrm{~m}$ & $1.45 \pm 1.22$ \\
$\mathrm{p}-\mathrm{F}$ & $0.021^{*}$ \\
$\mathrm{p}-\mathrm{t}$ & $<0.0001^{* *}$ \\
$2 \mathrm{~m}$ & $4.63 \pm 2.34$ \\
$10 \mathrm{~m}$ & $0.99 \pm 0.95$ \\
$\mathrm{p}-\mathrm{F}$ & $0.002^{*}$ \\
$\mathrm{p}-\mathrm{t}$ & $<0.0001^{* *}$ \\
$2 \mathrm{~m}$ & $4.63 \pm 2.34$ \\
$15 \mathrm{~m}$ & $1.03 \pm 0.93$ \\
$\mathrm{p}-\mathrm{F}$ & $0.001^{*}$ \\
$\mathrm{p}-\mathrm{t}$ & $<0.0001^{* *}$ \\
$5 \mathrm{~m}$ & $1.45 \pm 1.49$ \\
$10 \mathrm{~m}$ & $0.99 \pm 0.95$ \\
$\mathrm{p}-\mathrm{F}$ & 0.362 \\
$\mathrm{p}-\mathrm{t}$ & 0.267 \\
$5 \mathrm{~m}$ & $1.45 \pm 1.22$ \\
$15 \mathrm{~m}$ & $1.03 \pm 0.93$ \\
$\mathrm{p}-\mathrm{F}$ & 0.310 \\
$\mathrm{p}-\mathrm{t}$ & 0.305 \\
$10 \mathrm{~m}$ & $0.99 \pm 0.95$ \\
$15 \mathrm{~m}$ & $1.03 \pm 0.93$ \\
$\mathrm{p}-\mathrm{F}$ & 0.915 \\
$\mathrm{p}-\mathrm{t}$ & 0.908 \\
\hline
\end{tabular}

$p$-F, Two-tailed $p$-value of Fisher's $F$ test; $p$-t, two-tailed $p$-value of Student's t test; *, significant at the level of the significance alpha $=0.05 ;{ }^{* *}$, significant at the level of the significance alpha $=0.01$.

The different results in this study indicate that the transgene outflow rates could be influenced by many factors investigated. In all the sites, mean of outflow rates at the near proximity from the source $(2 \mathrm{~m})$ was significantly different from those of other distance while there was no difference within these last ones compared two by two.

As reported by other authors in many countries, transgene outflow decrease with increasing distance to the transgenes source. In Australia, Llewellyn and Fitt (1996) detected $0.4 \%$ at $1 \mathrm{~m}$ and $0.03 \%$ at $16 \mathrm{~m}$. In Mississippi (USA), Berkey and Savoy (2002) reported $1.89 \%$ at $1 \mathrm{~m}$, $0.13 \%$ at $16 \mathrm{~m}$ and outflow rates become like undetectable up to $24 \mathrm{~m}$. In California (USA), Van Deynze et al. (2005) reported transgene outflow of $7.65,0.67$ and $0.32 \%$, respectively at $0.3,9$ and $30 \mathrm{~m}$ affected by providing bees in the field. Variations of transgene outflow across countries and sites could be explained by the importance (in number and diversity) of different natural pollinator presence (Karieva et al., 1994; Vincenza and Marina 2001, Hamilton et al., 2002). According to this current study, it is also suggested to take into account the farming system (size of fields, pest control measures, among others).

Results also showed difference between means of the East side and West side at $2 \mathrm{~m}$ and between the East and South at $5 \mathrm{~m}$. But these results must be clarified because influence of climatic conditions on cotton pollen is not evident (Van Deynze et al., 2005). In self-pollinated crops like millet, cotton and tomatoes, effect of open pollination (by wind or insects) is negligible (Wang et al., 1997; Vincenza and Marina, 2001); when self-pollination is prevailing it favors self pollen grain when competing with foreign pollen (Robert et al., 1991). In contrast, on open-pollinated crops such as maize, sorghum, colza, open pollinators like wind (intensity and direction) and insects become important factors of pollen outflow (Vaissière and Vinson, 1994; Chèvre et al., 1997; Jarosz, 2003).

According to many authors (Chèvre et al., 1997; Jarosz, 2003; Van Deynze et al., 2005) while pollen outflow is sporadic and very low up to certain distance to pollen source, it is wrong to consider pollen flow as nil at long distances. In our study, no transgene flow was detected beyond $25 \mathrm{~m}$ to the source which could be explained by insecticide sprayed through the crop-growing season to protect the cotton. As reported by Vincenza and Marina (2001) and Hamilton et al. (2002), insecticides use reduces pollinators which are responsible for long gene outflow concern. Then, farming system must be taken into account to manage the transgenic crop release.

\section{Conclusion}

Transgene outflow was a real biosafety concern during the assessment of transgenic crops in Burkina Faso before its adoption. Its investigation was carried out in three research centres during three years. In our study conditions, transgene flow occurred with a relatively high rate in the immediate environs of the source of transgenes as the rate at this distance was different and high compare to those of most distant.

Climatic conditions and pest control application seem to influence the transgene flow, respectively, at the proximity and most distant from the source of pollen but these results must be more investigated at large farm scale and in condition of replications. All the results of this study must be completed by assessing transgene outflow in condition of many small fields of varying crops openspaced or contiguous as standard practices in Burkina; this is possible because transgenic cotton was adopted in commercial farming since 2010. Therefore it appears necessary that cotton relatives collected before this commercial release of $\mathrm{Bt}$ cotton be evaluated for their ability to outcross with the transgenic cotton even if some strategies have been imposed to prevent transgene outflow and to maintain transgenic cotton seed purity for a long time. 
Table 2. Relation between geographical orientations and transgene outflow regarding distance from transgenes source.

\begin{tabular}{|c|c|c|c|c|c|}
\hline \multirow{2}{*}{ Objects compared and tests used } & \multicolumn{5}{|c|}{ Distance from the transgenes source } \\
\hline & $2 \mathrm{~m}$ & $5 \mathrm{~m}$ & $10 \mathrm{~m}$ & $15 \mathrm{~m}$ & All distances combined \\
\hline East & $3.00 \pm 1.00$ & $0.67 \pm 0.58$ & $0.67 \pm 1.15$ & $\begin{array}{c}0.67 \pm \\
0.58\end{array}$ & $1.25 \pm 1.29$ \\
\hline South & $6.00 \pm 1.73$ & $2.33 \pm 0.58$ & $0.67 \pm 0.58$ & $\begin{array}{c}1.00 \pm \\
1.00\end{array}$ & $2.50 \pm 2.39$ \\
\hline $\mathrm{p}-\mathrm{F}$ & 0.500 & 1.000 & 0.400 & 0.500 & 0.051 \\
\hline $\mathrm{p}-\mathrm{t}$ & 0.060 & 0.024 * & 1.00 & 0.643 & 0.125 \\
\hline East & $3.00 \pm 1.00$ & $0.67 \pm 0.58$ & $0.67 \pm 1.15$ & - & $1.25 \pm 1.29$ \\
\hline West & $7.67 \pm 1.53$ & $2.00 \pm 2.00$ & $1.00 \pm 1.00$ & - & $2.67 \pm 3.31$ \\
\hline $\mathrm{p}-\mathrm{F}$ & 0.600 & 0.154 & 0.86 & - & 0.004 * \\
\hline $\mathrm{p}-\mathrm{t}$ & 0.011 * & 0.329 & 0.725 & & 0.181 \\
\hline South & $6.00 \pm 1.73$ & $2.33 \pm 0.58$ & $0.67 \pm 0.58$ & - & $2.50 \pm 2.39$ \\
\hline West & $7.67 \pm 1.53$ & $2.00 \pm 2.00$ & $1.00 \pm 1.00$ & - & $2.67 \pm 3.31$ \\
\hline$p-F$ & 0.875 & 0.154 & 0.500 & - & 0.296 \\
\hline$p-t$ & 0.279 & 0.795 & 0.643 & & 0.889 \\
\hline
\end{tabular}

$p$-F, Two-tailed p-value of Fisher's F test; p-t, two-tailed p-value of Student's t test; ${ }^{*}$, significant at the level of the significance alpha $=0.05$; ${ }^{* *}$, significant at the level of the significance alpha $=0.01$.

Table 3: Relation between the transgene outflow and pest control treatments.

\begin{tabular}{|c|c|c|c|c|c|}
\hline \multirow{2}{*}{ Objects compared and tests used } & \multicolumn{5}{|c|}{ Distance from the transgenes source } \\
\hline & $2 \mathrm{~m}$ & $5 \mathrm{~m}$ & $10 \mathrm{~m}$ & $15 \mathrm{~m}$ & All distances combined \\
\hline Boni untreated & $4.17 \pm 6.15$ & $1.11 \pm 2.21$ & $0.42 \pm 0.86$ & $1.68 \pm 2.77$ & $1.84 \pm 3.76$ \\
\hline $\mathrm{p}-\mathrm{F}$ & 0.095 & 0.186 & $0.001 *$ & $0.0001 *$ & 0.002 * \\
\hline$p-t$ & 0.382 & 0.692 & 0.650 & 0.044 * & 0.170 \\
\hline Kouaré untreated & $2.36 \pm 2.47$ & $1.11 \pm 1.90$ & $2.23 \pm 3.20$ & $1.82 \pm 2.49$ & $1.88 \pm 2.54$ \\
\hline$p-F$ & 0.907 & 0.122 & 0.001 * & $0.000 * *$ & 0.036 * \\
\hline$p-t$ & 0.656 & 0.355 & 0.07 & 0.049 * & 0.016 * \\
\hline
\end{tabular}

$\mathrm{p}-\mathrm{F}$, Two-tailed $\mathrm{p}$-value of Fisher's $\mathrm{F}$ test; $\mathrm{p}$-t, two-tailed $\mathrm{p}$-value of Student's $\mathrm{t}$ test; ${ }^{*}$, significant at the level of the significance alpha $=$ $0.05 ;{ }^{* *}$, significant at the level of the significance alpha $=0.01$.

\section{REFERENCES}

Andow DA, Zwahlen C (2006). Assessing environmental risks of transgenic plants. Ecol. Lett. 9: 196-214.

Berben G, Jassen E, Debode F (2000). Détection, identification et quantification des transgènes dans les aliments par amplification génique. Biotechnol. Agron. Soc. Environ. 4(4): 208-213.

Berkey DA, Savoy VR (2002). Pollen dissemination from adjacent fields of genetically enhanced cotton in the Mississippi Delta. Beltwide Cotton Conference, Atlanta, GA, 8-12 Jan. 2002. pp.5.

Cfia, Pbo (2003). Détermination de l'innocuité du cotonnier BollgardII ${ }^{\text {md }}$ (Gossypiumhirsutum L.) résistant aux insectes de Monsanto. Document de décision DD2003-45 pp. 12.

Chèvre AM, Eber F, Vallée P, Pierre J, Renard M (1997). Impact de la transformation écologique du colza. In: Biotechnologies, Amélioration des plantes et Sécurité Alimentaire. Actes des $6^{\text {èmes }}$ Journées Scientifiques du Réseau AUPELF. UREF « Biotechnologies Végétales : Génie Génétique des plantes " Université de Paris Sud XI, Centre Universitaire d'Orsay (France) du 30 juin-3 juillet 1997: 189-197.
Hamilton KA, Goodman RE, Fuchs RL (2002). Safety assessment of insect protected cotton. In: Thomas JA, Fuchs RL (eds). Biotechnology and Safety Assessment.Academic Press, Amsterdam. pp 435-465.

Hema SAO (2004). Contribution à la caractérisation biochimique de la résistance de Helicoverpaarmigera (Hübner, 1808) (Lepidoptera, Noctuidae) aux pyréthrinoïdes au Burkina Faso. Mémoire de D.E.A., Ecole Doctorale Régionale de Biotechnologie, Université de Ouagadougou. pp. 37.

James $C$ (2002). Global Review of Commercialized Transgenic Crops: 2001 Feature: Bt cotton. ISAAA Briefs No. 26. ISAAA: Ithaca, NY. pp. 40.

Jarosz N (2003). Etude de la dispersion atmosphérique du pollen de maîs : contribution à la maîtrise des risques de pollinisation croisée. Thèse de doctorat, Institut National Agronomique Pais-Grignon. Ecole doctorale ABIES (France). pp. 125.

Karieva P, Morris W, Jacobi CM (1994). Studing and managing the risk of cross-fertilisation between transgenic crops and wild relatives. Mol. Ecol. 3: 15-21.

Lagandre D (2005). Le secteur cotonnier en zone franc, entre succès et 
dépendance. Agence Française de Développement, Paris, France. Rapport JUMBO No 7, pp. 24.

Llewellyn D, Fitt G (1996). Pollen dispersal from two fields trials of transgenic cotton in the Namoi Valley, Australia. In: Molecular Breeding: new strategies in plant improvement. International Soc. for plant molecular biology, Dordrecht; Boston: Kluwer Academic Publishers. pp.157-166.

Malone AL, Pham-Delegue M-H (2001). Effects of transgene products on honey bees (Apis mellifera) and bumble bees (Bombus sp.). Apidologie 32: 1-18.

Martin T, Ochou GO., Hala NF., Vassal JM., Vaissayre M (2000). Pyrethroid resistance in the cotton bollworm, Helicoverpa armigera (Hübner), in West Africa. Pest Manage. Sci. 56: 549-554

Messean A, Angevin F, Gomez-Barbero M, Menrad K, Rodrgez-Cerezo $E$ (2006). New case studies on the coexistence of GM and non-GM crops in European agriculture. EU commission Joint Research Centre. Technical Report Series, EUR22102EN. 116p. http://www.jrc.cec.eu.int/download/GMCrops_coexistence.pdf consulté le 15/08/2005.

Messeguer J, Marfà V, Català MM, Guiderdoni E, Melé E (2004). A field study of pollen-mediated gene flow from Mediterranean GM rice to conventional rice and the red rice weed. Mol. Breed. 13: 103-112.

Mikkelsen TR, Anderson B, Jorgensen RB (1996). The risk of transgene spread. Nature 31: 380-380.

Omer SAH, Konaté G, Traoré O, Traoré O, Menozzi P (2009). Biochemical characterization of the cotton bollworm Helicoverpaarmigera resistance to pyrethroids in Burkina Faso. Pak. J. Biol. Sci. 12 (13): 964-969

Perlak F, Oppenhuizen M, Gustafson K, Voth R, Sivasupramanian S, Heering D (2001). Development and commercial use of Bollgard ${ }^{A}$ cotton in USA -early promises versus today's reality. Plant J. 27: 489502.

Robert T, Lespinasse R, Pernes J, Sarr A (1991). Gametophytic competition as influencing gene flow between wild and cultivated forms of pearl millet (pennisetum typhoïdes). Genome 34: 195-200.
Squire GR, Augustin N, Bown J, Crawf JW, Dunop G, Graham J, Hilman JR, Marshall B, Marshall D, Ramsay G, Robinson DJ (1999). Gene flow in the environment-genetic pollution? BCPC Symposium Proceedings No. 72, 45-54. British Crop Protection Council Farnham, Surrey.

Traore D (1999). Entomologie et expérimentation phytosanitaire sur cotonnier. Rapport annuel de campagne agricole 1998-1999, P. 59.

Vaissière BE, Vinson SB (1994). Pollen morphology and its effect on pollen collection by honey bees, Apis mellifera L. (Hymenoptera: Apidae) with special reference to upland cotton, Gossypium hirsutum L. (Malvaceae). Grana 33: 128-138.

Van Deynze A, Sundstrom FJ, Bradford KJ (2005). Pollen Mediated Gene Flow in California Cotton Depends on Pollinator Activity. Crop Sci. 45: 1565-1570.

Vincenza I, Marina B (2001). Assessment of functional transgene flow in tomato fields. Mol. Breed. 8(4): 311-315.

Vitale J, Glick H, Greenplate J, Abdennadhercand M, Traoré O (2008). Second-Generation Bt Cotton Field Trials in Burkina Faso: Analyzing the Potential Benefits to West African Farmers. Crop Sci. 48 (5): 1958-1966.

Wang TY, Chien HB, Reboud X, Darmency H (1997). Pollen-mediated gene flow in an autogamous crop: Foxtail millet (Setaria italica). Plant Breed. 116: 579-583. 